\title{
Critical Posthumanism, Again
}

\section{Stefan Herbrechter}

Arguably, what has come to be known as "critical posthumanism" took off from a specific place and intellectual climate in the 1990s and early 2000s.' It arose out of the (now defunct) Cardiff Centre for Critical and Cultural Theory, which, at the time, was one of the leading places for (British) poststructuralism and (French) Theory-a combination of Barthesian semiology, Foucauldian genealogy and biopolitics, Althusserian Marxism, Derridean deconstruction, cultural materialism, Lacanian psychoanalysis, Lyotard's inhumanism, Cixous' écriture féminine, Said's orientalism, and Spivak's and Bhabha's postcolonialism. One probably recognizes poststructuralists by the way they use the notion of the subject in and of ideology, subscribe to a generalized idea of textuality and inscription, and emphasize the materialist and political dimension of representation, as well as media and communication more generally. Poststructuralism's stance has been antihumanist, in the form of an attack on the liberal humanist tradition (as the dominant ideology that interpellates human subjects as free individuals while, at the same time, aligning freedom merely with a choice of commodities and consumption with identity, with the aim of shoring up the hegemony of global and neoliberal capitalism). From the start, poststructuralism was therefore also critical of humanism's claims towards universalism, its repression of difference, and its essentialist notion of identity.

Critical posthumanism is a continuation, extension, and, in many respects, radicalization of this poststructuralist critique under new conditions. Global historical events and developments (such as the end of the Cold War, 9/11 and the global war on terror, accelerated and human-induced climate change, the 2008 financial crisis, COVID-19) and technological and media change (digitalization, bio- and geoengineering) have led to shifts and transformations in theory ("after" theory) in order to be able to explain new forms of subjectivity, postanthropocentric notions of politics, ethics and justice, and new ontologies and materialisms.

If one is looking for an iconic figure for this post- or nonhuman turn it is probably a safe bet to look towards Donna Haraway's idea of the cyborg as a deconstructive figure. The cyborg highlights the impossibility of a radical distinction between human/animal and human/machine, both from a contemporary point of view (i.e. under technocultural and technoscientific conditions), but also genealogically (i.e. by looking back at the history of Western metaphysics, its inclusions and exclusions, its policing of boundaries; especially between the human and the nonhuman) and its practices of "ontological hygiene" (Elaine Graham's term). Critical posthumanism

\footnotetext{
1 To be even more precise, I think it started in a PhD reading group on Lyotard's The Inhuman (1992) around 1996. Regularly present were Neil Badmington, Ivan Callus, Simon Malpas, Laurent Milesi, and myself. Neil went on to edit a reader entitled Posthumanism (Badmington 2000), arguably the first publication that explicitly sees posthumanism as the "ongoing deconstruction of humanism" (see below). Of course, others had prepared the ground for this-Donna Haraway as early as 1985 in her "Cyborg Manifesto" (in Haraway 1991); Cary Wolfe as early as 1998 in his first text on Derridean deconstruction and Luhmannian systems theory (Wolfe 1998); and certainly N. Katherine Hayles's How We Became Posthuman (1999), which opens up the critique of cybernetics and the question of (posthuman) disembodiment. Also, important and often unfairly neglected today is Elaine Graham's Representing the Post/Human (2002). However, it is this peculiar mix of ideas and reading practices deriving out of what could be called the "Cardiff School" of the time that can explain the shifts from "sign to trace," the focus on and problematization of the idea of taking postanthropocentrism "literally," and of how to read from a "posthumanist" point of view, that I would claim as recognizable gestures of "critical posthumanism" (see Herbrechter 2009 and 2013).
} 
begins, strategically, with a critical engagement with science fictional utopian visions while, at the same time, continuing to perform a critique of humanist tradition and human self-understanding. Instead it promotes a vision of the human, "its" environment and nonhuman "others" that is postanthropocentric. It opposes the idea of human exceptionalism.

Critical Posthumanism is thus looking forward and backward at the same time in order to, on the one hand, resist the dehumanizing tendencies of late global technoscientific biopolitical capitalism and anthropogenic climate change (i.e. "our" time), and, on the other hand, to rewrite the anthropocentrism of the humanist tradition by emphasizing differences within the very category of the human (e.g. gender, age, race, species) in the search for "multispecies justice" (Haraway's term). In other words, a critical posthumanism, thus understood, is the "ongoing deconstruction of humanism" and certainly not the idea that we can or will soon be able to simply leave that humanist tradition behind. It is even less the phantasm of some kind of transhumanist transcendence of the human or the preparation for some superhuman intelligence.

This is why it is so important to differentiate between posthumanism (and posthumanist) as a discourse and the posthuman as a figure. Posthumanism as a discourse (in the Foucauldian sense) produces knowledge about questions like: "Who or what comes after the human?" or "Have we ever been human?" and "Under what conditions does it make sense to speak of "humanity' at all?" It proceeds by "finding", constructing, and proliferating alternative posthuman figures and practices. It shows that we have never been human in the way that traditional humanism (or indeed transhumanism) want to make us believe. Instead, it starts from the assumption that there is no human essence that makes "us" fundamentally different from other nonhuman animals and other others, including technical and inorganic ones. It is predicated on a process of becoming human "otherwise"-a process one might call posthumanisation-and which is originary, in the sense that "we" have always been in the process of becoming (with) other(s). Deflecting-deconstructing-humanism is the only way to open up a future that promises justice to both humans (their unquestionable achievements and future development) and nonhuman others (their differences, their alterities but also their undeniable similarities).

\section{References}

Badmington, N., ed. (2000). Posthumanism. Houndmills: Palgrave.

Graham, E. (2002). Representations of the Post/Human. Manchester: Manchester University Press.

Haraway, D. (1991). Simians, Cyborgs, and Women. New York: Routledge.

Haraway, D. (2007). When Species Meet. Minneapolis: University of Minnesota Press.

Hayles, N. K. (1999). How We Became Posthuman. Chicago: University of Chicago Press.

Herbrechter, S. (2009). Posthumanismus - Eine kritische Einführung. Darmstadt: Wissenschaftliche Buchgesellschaft.

Herbrechter, S. (2013). Posthumanism: A Critical Analysis. London: Bloomsbury. 
Lyotard, J.F. (1992). The Inhuman: Reflections on Time. Trans. Geoffrey Bennington and Rachel Bowlby. Stanford: Stanford University Press.

Wolfe, C. (1998). Critical Environments. Minneapolis: University of Minnesota Press.

Wolfe, C. (2010). What is Posthumanism? Minneapolis: University of Minnesota Press. 